\title{
ANALISIS PERLAKUAN AKUNTANSI KEWAJIBAN PADA PERUSAHAAN AIR MINUM (PAM) TIRTA MANGKALUKU KOTA PALOPO
}

\author{
Desi Rahmawati \\ Jurusan Akuntansi Audit Internal, Universitas Muhammadiyah (UM) Palopo \\ desirahmawati@gmail.com
}

\begin{abstract}
ABSTRAK
Penelitian ini bertujuan Untuk mengetahui bagaimana penyajian akuntansi kewajiban dalam laporan keuangan pada Perusahaan Daerah Air Minum Tirta Mangakaluku Kota Palopo. Penelitian ini menggunakan metode deskriptif yaitu dengan mendeskrifsikan akuntantansi kewajiban yang terjadi pada Perusahaan Air Minum (PAM) Tirta Mangkaluku Kota Palopo dengan kesesuaian pada laporan berbasis Standar Akuntansi Keuangan Entitas Tanpa Akuntabilitas Publik (SAK ETAP) sehingga dapat ditarik kesimpulan bahwa hasil peneltian ini sudah sesuai dengan Standar Akuntansi Keuangan Entitas Tanpa Akuntabilitas Publik (SAK ETAP) dimana Akuntansi Kewajiban diakui dalam neraca jika kemungkinan pengeluaran sumber daya yang mengandung manfaat ekonomi akan dilakukan untuk menyelesaikan kewajiban masa kini dan jumlah yang harus diselesaikan dapat diukur dengan andal dan Kewajiban dicatat sebesar nilai nominal. Kewajiban jangka pendek berkurang pada saat pembayaran/penyelesaian oleh perusahaan.
\end{abstract}

Kata Kunci: Standar Akuntansi Keuangan Entitas Tanpa Akuntabilitas Publik (SAK ETAP), Pengakuan Kewajiban, Pengukuran Kewajiban.

\section{ABSTRACT}

This study aims to determine how the presentation of liability accounting in financial statements at Tirta Mangakaluku Municipal Water Company Palopo City. This study uses a descriptive method that is by describing the accountability of liabilities that occur at the Tirta Mangkaluku Municipal Water Supply Company (PAM) in accordance with the report based on the Financial Accounting Standards of Entities without Public Accountability (SAK ETAP) so that it can be concluded that the results of this study are in accordance with The Financial Accounting Standards for Entities Without Public Accountability (SAK ETAP) where the Obligatory Accounting is recognized in the balance sheet if the possible expenditure of resources containing economic benefits will be carried out to settle current obligations and the amount to be settled can be measured reliably and the liabilities are recorded at face value. Short-term liabilities are reduced at the time of payment/settlement by the company.

Keywords: Financial Accounting Standards for Entities Without Public Accountability (SAK ETAP), Recognition of Obligations, Measurement of Obligations.

\section{PENDAHULUAN}

\section{Latar Belakang}

Standar Akuntansi Keuangan (SAK) merupakan salah satu standar yang harus diterapkan oleh perusahaan dalam membuat laporan keuangannya. Standar ini sewaktu-waktu dapat berubah sesuai dengan peraturan-peraturan yang dikeluarkan oleh pemerintah. Perusahaan mengacu pada Standar Akuntansi Keuangan Entitas Tanpa Akuntabilitas Publik dan perusahaan belum menghitung besaran imbalan kerja dan menyajikannya dalam laporan keuangan yang diatur pada Bab 23 SAK ETAP.

Perusahaan Air Minum (PAM) Tirta Mangkaluku Kota Palopo merupakan salah satu perusahaan milik Daerah Propinsi atau Daerah Kabupaten dan atau Daerah Kota yang bergerak dibidang pengelolaan dan penyediaan air bersih. Perusahaan Air Minum (PAM) Tirta Mangkaluku Kota Palopo merupakan perusahaan yang tidak hanya beroreantasi pada masyarakat, tetapi juga beroreantasi pada menghasilkan laba. Laba yang dihasilkan oleh 
perusahaan sebagian digunakan untuk kegiatan operasional perusahaan dan sebagian lagi disetorkan ke kepemrintah guna meningkatkan pendapatan asli daerah. Dengan berkembangnya Perusahaan Air Minum (PAM) Tirta Mangkaluku Kota Palopo yang sedemikian rupa ini, kiranya sudah cukup disadari bahwa Perusahaan Air Minum merupakan suatu usaha pelayanan air minum yang perlu dikelola secara profesional karena menyerap banyak tenaga kerja, dana dan prasarana.

Implementasi SAK ETAP dapat mempermudah Perusahaan Air Minum (PAM) dalam menyusun laporan keuangan, dimana pengaturan dan perhitungannya akan lebih sederhana karena memang ditujukan untuk usaha menengah kebawa. Penyajian laporan keuangan yang sesuai dengan standar yang telah ditentukan, akan membantu manajemen perusahaan untuk memperoleh

Dengan adanya pembangunan didaerah yang dipacu melalui sarana dan prasarana maka pemerintah daerah harus lebih giat lagi untuk mencari sumber- sumber dana yang menanggulangi hal apa saja yang dibutuhkan oleh daerah untuk

kemaslahatan umum. Dalam laporan keuangannya terdapat sumber-sumber aset, kewajiban, modal, pendapatan biaya yang dalam hal ini dapat memperlancar kegiatan-kegiatan program pemerintah.Dalam laporan kegiatan juga ada yang namanya laporan neraca yang berisi salah satunya aset pemerintah yaitu konstruksi dalam pengerjaan.

Pendanaan melalui hutang yang tinggi mengakibatkan masalah financial distress. Teori ini menyatakan bahwa perusahaan harus bisa menyeimbangkan komposisi hutang dalam kombinasi struktur modalnya sehingga diperoleh komposisi hutang dan saham yang optimal dengan analisis perhitungan keuangan yang tepat (Steven, 2011).

Pada penelitian ini, peneliti memfokuskan untuk membahas perlakuan akuntansi kewajiban dalam hal penyajian dan pengungkapan dalam laporan keuangan sesuai dengan standar akuntansi yang berlaku.

\section{Rumusan masalah}

Berdasarkan uraian latar belakang yang telah dipaparkan, maka dapat dirumuskan permasalahan penelitian yaitu:Bagaimana penyajian akuntansi kewajiban dalam laporan keuangan Perusaha Daerah Air Minum Tirta Mangkaluku Kota Palopo?

\section{Tujuan Penelitian}

Berdasarkan permasalahan tersebut maka tujuan yang diharapkan dalam penelitian ini yaitu:Untuk mengetahui bagaimana penyajian akuntansi kewajiban dalam laporan keuangan 
pada Perusahaan Daerah Air Minum Tirta Mangakaluku Kota Palopo.

\section{TINJAUAN PUSTAKA}

\section{Teori Stakeholders}

Stakeholders merupakan semua pihak baik internal maupun eksternal yang mempunyai hubungan yang bersifat mempengaruhi maupun dipengaruhi, bersifat langsung maupun tidak langsung oleh perusahaan. Batasan stakeholders, karena mereka adalah pihak yang dipengaruhi dan mempengaruhi baik langsung maupun tidak langsung atas aktivitas atas kebijakan yang diambil oleh perusahaan. Jika perusahaan tidak menghasilkan stakeholders bukan tidak mungkin akan menuai protes dan dapat mengeliminasi legitimasi stakeholders (Hadi, 2011).

Menurut teori stakeholders, manajemen organisasi diharapkan melakukan kegiatan yang dianggap penting oleh stakeholders mempunyai hak untuk disediakan informasi tentang bagaimana kegiatan organisasi memengaruhi mereka, bahkan mereka memilih untuk tidak menggunakan informasi tersebut dan bahkan ketika mereka tidak secara langsung melakukan peran konstruktif dalam kelangsungan hidup organisasi.

\section{Akuntansi Kewajiban}

Akuntansi Kewajiban adalah utang yang timbul dari peristiwa masa lalu yang penyelesaiannya mengakibatkan aliran keluar sumber daya ekonomi pemerintah Dalam konteks pemerintahan, kewajiban muncul antara lain karena penggunaan sumber pendanaan pinjaman masyarakat, lembaga keuangan, entitas pemerintahan lain, atau lembaga internasional. Kewajiban pemerintah dapat juga terjadi karena perikatan dengan pegawai yang bekerja pada pemerintah, kewajiban kepada masyarakat luas, yaitu kewajiban tunjangan, kompensasi, ganti rugi, kelebihan setoran pajak dari wajib pajak, alokasi/realokasi pendapatan ke entitas lainnya, atau kewajiban dengan pemberi jasa lainnya. Setiap kewajiban dapat dipaksakan menurut hukum sebagai konsekuensi dari kontrak yang mengikat atau peraturan perundang-undangan (Erlina 2015)

\section{Klasifikasi Kewajiban}

\section{a. Kewajiban Jangka Pendek}

Kewajiban jangka pendek merupakan kewajiban yang diharapkan dibayar dalam waktu 12 (dua belas) bulan setelah tanggal pelaporan. Kewajiban jangka pendek dapat dikategorikan dengan cara yang sama seperti aset lancar. Beberapa kewajiban jangka pendek, seperti utang transfer pemerintah atau utang kepada pegawai merupakan suatu bagian yang akan menyerap aset lancar dalam tahun pelaporan berikutnya. 


\section{b. Kewajiban Jangka Panjang}

Kewajiban jangka panjang merupakan kewajiban yang jatuh tempo lebih dari 12 bulan. Jika pada akhir periode akuntansi, pemerintah mempunyai utang jangka panjang, maka pemerintah harus melakukan reklasifikasi kewajiban tersebut ke kewajiban jangka pendek dan kewajiban jangka panjang( Erlina 2015).

\section{Pengakuan Kewajiban}

Pada dasarnya dapat dikatakan secara singkat bahwa kewajiban diakui apabila besar kemungkinan terjadi pengeluaran sumber daya ekonomi. Secara lengkap, kewajiban diakui jika besar kemungkinan bahwa pengeluaran sumber daya ekonomi akan dilakukan untuk menyelesaikan kewajiban yang ada sampai saat pelaporan, dan perubahan atas kewajiban tersebut mempunyai nilai penyelesaian yang dapat diukur dengan andal.

PSAP No. 9 tentang Akuntansi Kewajiban, mengatakan bahwa suatu transaksi dengan pertukaran timbul ketika masing-masing pihak dalam transaksi tersebut mengorbankan dan menerima suatu nilai dengan gantinya

\section{METODE PENELITIAN}

\section{Lokasi Penelitian}

Berdasarkan pada judul penelitian, maka penelitian ini dilaksanakan di Perusahaan Air Minum (PAM) Tirta Mangkaluku Kota Palopo.

\section{Instrumen Penelitian}

Dalam penelitian kualitatif, peneliti merupakan instrumen utama dalam mengumpulkan data dan menginterprestasikan data dengan bimbingan oleh pedoman observasi. Dengan mengadakan observasi mendalam dapat memahami makna interaksi sosial, mendalami perasaan dan nilai-nilai yang tergambar dalam ucapan dan perilaku responden.Agar peneliti ini terarah, peneliti terlebih dahulu menyusun kisi-kisi instrumen penelitian yang selanjutnya dijadikan acuan untuk membuat pedoman wawancara dan obsevasi.

\section{Sumber Data}

Sumber data yang digunakan adalah Data Sekunder. Data sekunder adalah data yang dikumpulkan dari data kedua yaitu dari intansi yang berhubungan laporan keuangan sebelum penelitian di lakukan. Data sekunder diperoleh dari jurnal ilmia, buku, laporan-laporan atau arsip organisasi, publikasi pemerintah, analisis para ahli, hasil survei terdahulu, catatan publik dan perpustakaan. Data sekunder yang dimaksud adalah berupa Laporan Keuangan Perusahaan Air Minum (PAM) Tirta Mangkaluku Kota Palopo. 


\section{MetodePengumpulan Data}

Untuk mendapatkan data-data tersebut maka penulis akan menggunakan instrument Observasi, dalam instrument observasi penulis akan melakukan pengamatan dilokasi penelitian untuk mendapatkan gambaran yang tepat mengenai subjek dan objek penelitian.

\section{Metode Analisis Data}

Metode penelitian yang digunakan peneliti dalam penyusunan skripsi ini adalah metode deskriptif. Penelitian deskriptif hanyalah memaparkan situasi atau peristiwa. Penelitian ini tidak mencari atau menjelaskan hubungan, tidak menguji hipotesis atau membuat prediksi (Rakhmat, 2012:24).

\section{HASIL PENELITIAN DAN PEMBAHASAN}

Adapun posisi kewajiban jangka panjang maupun kewajiban jangka pendek dalam 3 tahun terakhir yaitu pada tahun 2015, 2016 dan 2017 yaitu:

Tabel 4.1 Kewajiban Jangka Pendek

\begin{tabular}{|c|c|c|c|c|}
\hline No. & Nama akun & $\begin{array}{l}2015 \\
(\mathrm{Rp})\end{array}$ & $\begin{array}{l}2016 \\
(\mathrm{Rp})\end{array}$ & $\begin{array}{l}2017 \\
(\mathrm{Rp})\end{array}$ \\
\hline 1. & Hutang usaha & $1,709,684,000$ & $1,862,565,802$ & $1,526,092,874$ \\
\hline 2. & $\begin{array}{l}\text { Biaya yang masih } \\
\text { harus dibayar }\end{array}$ & $89,637,024.00$ & $96,951,262.00$ & $147,731,850.00$ \\
\hline 3. & $\begin{array}{l}\text { Hutang Jangka Panjang } \\
\text { Yang Jatuh } \\
\text { Tempo }\end{array}$ & - & - & - \\
\hline 4. & $\begin{array}{l}\text { Hutang Perbankan } \\
\text { Yang Jatuh Tempo }\end{array}$ & - & $2,110,461,250$ & $2,162,000,000$ \\
\hline 5. & $\begin{array}{l}\text { Hutang Lancar } \\
\text { Lainnya }\end{array}$ & $481,231,280$ & $522,157,621$ & $431,259,176$ \\
\hline & $\begin{array}{l}\text { JUMLAH } \\
\text { KEWAJIBAN } \\
\text { JANGKA PENDEK }\end{array}$ & $2,280,552,304$ & $4,592,135,935$ & $4,267,083,900$ \\
\hline
\end{tabular}

Sumber: Data PAM Tirta Mangkaluku Kota Palopo

Kewajiban Jangka Pendek adalah kewajiban yang likuiditasnya diperkirakan secara layak memerlukan penggunaan sumber daya yang ada diklasifikasikan sebagai aktiva lancar atau penciptaan kewajiban lancar lain.Dalam kewajiban jangka pendek pada Perusahaan Air Minum (PAM) Tirta Mangkaluku Kota Palopo terdapat 5 unsur hutang yaitu, utang usaha, biaya yang 
masih dibayar, hutang jangka panjang yang jatuh tempo, hutang perbankan yang jatuh tempo, dan hutang lancar lainnya.

Dari tabel 4.1 yang diperoleh dari data laporan keuangan Perusahaan Air Minum (PAM) Tirta Mangkaluku Kota Palopo, terlihat utang usaha pada tahun 2015 sebesar Rp 1,709,684,000, pada tahun 2016 hutang usaha mengalami peningkatan, kemudian di tahun 2017 mengalami penurunan sebesar Rp 336.472.928 sehingga jumlah utang usaha sebesar Rp 1,526,092,874. Selanjutnya biaya yang masih harus dibayar pada tahun 2015 sebesar Rp 89,637,024.00, pada tahun 2016 dan tahun 2017 terus mengalami peningkatan yaitu 2016 sebesar Rp 96,951,262.00 dan tahun 2017 sebesar Rp 147,731,850.00. hutang perbankan yang jatuh tempo pada tahun 2015Perusahaan Air Minum (PAM) Tirta Mangakaluku Kota Palopo tidak memiliki hutang, kemudianpada tahun 2016 terdapat utang sebesar Rp 2,110,461,250. Dan pada tahun 2017 hutang perbankan yang jatuh tempo mengalami peningkatan sebesar Rp 2,162,000,000. Kemudian hutang lancar lainnya pada tahun 2015 sebesar Rp 481,231,280. Pada tahun 2016 mengalami peningkatan sebesar Rp 522,157,621 dan pada tahun 2017 Hutang lancar lainnya Perusahaan Air Minum (PAM) Tirta Mangkaluku Kota Palopo mengalami penurunan sebesar Rp 90,898,442 sehingga jumlah hutang lancar lainnya sebesar Rp 431,259,176.

Dilihat dari tabel 4.1, menunjukkan bahwa jumlah kewajiban jangka pendek dari tahun 2015 mengalami peningkatan dimana pada tahun 2015 jumlah kewajiban jangka pendek sebesar Rp 2.280.552.304 dan pada tahun 2016 sebesar Rp 4.592.135.935. sedangkan pada tahun 2017 dari tahun 2016 mengalami penurunan yaitu jumlah kewajiban jangka pendek pada tahun 2017 sebesar Rp 4.267.083.900.

Tabel 4.2 Kewajiban Jangka Panjang

\begin{tabular}{|c|l|c|c|c|}
\hline No. & \multicolumn{1}{|c|}{ Nama akun } & $\begin{array}{c}2015 \\
(\mathrm{Rp})\end{array}$ & $\begin{array}{c}2016 \\
(\mathrm{Rp})\end{array}$ & $\begin{array}{c}2017 \\
(\mathrm{Rp})\end{array}$ \\
\hline 1. & $\begin{array}{l}\text { Hutang Dalam } \\
\text { Negeri }\end{array}$ & - & - & - \\
\hline 2. & $\begin{array}{l}\text { Hutang Luar } \\
\text { Negeri }\end{array}$ & - & - & - \\
\hline 3. & Hutang Bank & $10,130,214,000$ & $14,773,228,750$ & $12,559,690,000$ \\
\hline 4. & $\begin{array}{l}\text { Hutang Non Pokok } \\
\text { yang akan } \\
\text { Dihapus }\end{array}$ & $9,719,626,935$ & - & - \\
\hline
\end{tabular}




\begin{tabular}{|l|l|c|c|c|}
\hline & JUMLAH & & & \\
KEWAJIBAN & $19,849,840,935$ & $14,773,228,750$ & $12,559,690,000$ \\
JANGKA & & & \\
\hline PANJANG & & & \\
\hline
\end{tabular}

Sumber : Data PAM Tirta Mangkaluku Kota Palopo

Kewajiban Jangka Panjang adalah kewajiban yang diperkirakan secara memadai tidak akan dilikuidasi dalam siklus operasi normal, melainkan aka dibayar diluar tanggal waktu tersebut. Dalam Kewajiban Jangka Panjang Perusahaan Air Minum (PAM) Tirta Mangkaluku Kota Palopo terdapat 5 unsur hutang yaitu, Hutang Dalam Negeri, Hutang Luar Negeri, Hutang Bank, dan Hutang Non Pokok Yang Akan Dihapus.

Dari tabel 4.2 yang diperoleh dari data laporan keuangan Perusahaan Air Minum (PAM) Tirta Mangkaluku Kota Palopo, dapat dilihat bahwa tiga tahun berturut-turut yaitu pada tahun 20152017 perusahaan ini tidak memiliki Hutang Dalam Negeri Dan Hutang Luar Negeri. Kemudian perusahaan ini memiliki Hutang Bank pada tahun 2015 sebesar Rp 10,130,214,000, pada tahun 2016 meningkat dengan jumlah Rp 14,773228,750, kemudian pada tahun 2017 hutang bank pada perusahaan ini mengalami penurun sehingga jumlah hutang bank tersebut sebesar Rp 12,559,690,000. Selanjutnya Hutang Non Pokok yang akan Dihapus pada tahun 2015 yaitu sebesar Rp 9,719,626,935 dan 2 tahun kedepan yaitu pada tahun 2016 sampai 2017 Perusahaan Air Minum Tirta Mangkaluku Kota Palopo tidak lagi memiliki Hutang Non Pokok yang akan Dibayar.

Dilihat dari tabel 4.2, menunjukkan bahwa jumlah kewajiban jangka panjang dari tahun 2015 sampai 2017 terus mengalami penurunan, dimana pada tahun 2015 jumlah kewajiban jangka panjang sebesar Rp 19.849.840.935 dan menurun pada tahun 2016 sebanyak Rp 5.076.612.185 dengan jumlah Rp 14.773.228.750. dan pada tahun 2017 menurun sebesar Rp 2.213.538.750 dengan jumlah Rp 12.559.690.000.

Hasil penelitian ini sejalan dengan sejalan dengan hasil penelitian Brigita (2016) bahwa penelitian ini sudah sesuai dengan Standar Akuntansi Keuangan Entitas Tanpa Akuntabilitas Publik (SAK ETAP). Secara sistem dan bentuk laporan yang dibuatnya telah sama dengan macam-macam laporan keuangan yang ada dalam ketetapan SAK ETAP. Penelitian ini juga sejalan dengan penelitian yang dilakukan Andi Pratama (2014) dengan adanya rancangan penerapan Standar Akuntansi Keuangan Entitas Tanpa Akuntabilitas Publik (SAK ETAP) memberikan kemudahan pada berbagai pihak dalam mengelola data-data perusahaan yang tersedia guna membuat laporan keuangan yang baku seta untuk melihat kinerja perusahaan yang tercermin dalam laporan keuangan. Sedangkan penelitian yuliza (2015) bahwa apabila dalam 
suatu perusahaaan memiliki pemahaman dan pengetahuan terkait Dengan Standar Akuntansi Keuangan Entitas Tanpa Akuntabilitas Publik (SAK ETAP) secara menyeluruh serta menguasai dengan baik, sehingga ketika melakuan pengungkapan dan pencatatan dilaporan keuangan dapat tersusun secara rapi dan sesuai dengan SAK ETAP. Sedangkan hasil penelitian ini tidak sejalan dengan hasil penelitian Alfitri, dkk (2014) karena dalam penelitiannya prusahaan tersebut kurang memiliki kemampuan dalam pencatatan dan penyusunan laporan keuangan berbasis SAK ETAP. Pencatatan dan penyusunan yang dibuat tidak sesuai dengan standar akuntansi dan tidak menerapkan SAK ETAP.

Berdasarkan penjelasan diatas dapat disimpulkan bahwa sebagian perusahaan menengah belum menggunakan atau menerapkan Standar Akuntansi Keuangan Entitas Tanpa Akuntabilitas Publik (SAK ETAP) pada penyusunan laporan keuangannya. Persamaan penelitian ini dengan penelitian sebelumnya adalah jenis penelitian kualitatif deskriptif. Dan perbedaan penelitian ini dengan penelitian-penelitian terdahulu yaitu pada lokasi yang menjadi objek penelitian. Penelitian ini dilakukan pada Perusahaan Air Minum (PAM) Tirta Mangkaluku Kota Palopo.

\section{PENUTUP}

\section{Simpulan}

Berdasarkan pokok permasalahan, tujuan penelitian dan pembahasannya, dapat dikemukakan kesimpulan hasil penelitian menunjukkan bahwa Perlakuan Akuntasi Kewajiban yang diterapkan oleh Perusahaan Daerah Air Minum (PDAM) Tirta Mangkaluku Kota Palopo telah sesuai dengan Standar Akuntansi Keuangan Entitas Tanpa Akuntabilitas Publik (SAK ETAP).

\section{Saran}

Beberapa saran dalam penelitian ini yaitu pertama, perlunya memperluasa objek penelitian, tidak hanya 1 perusahaan saja sehingga lebih dapat dijadikan acuan kepentingan generalisasi permasalahan. Kedua, bagi penelitian selanjutnya diharapkan dapat meneliti lebih dalam yang tidak hanya terbatas pada 1 variabel yang diteliti, melainkan perlu adanya penambahan variabel lainnya serta diharapkan dapat menggunkan variabel penelitian selain dari variabel yang diteliti oleh penulis. Ketiga, peneliti selanjutnya diharapkan untuk mengkaji lebih banyak sumber maupun referensi yang terkait dengan apa yang objek yang diteliti agar hasil penelitiannya dapat lebih baik dan lebih lengkap lagi. Keempat, Peneliti selanjutnya diharapkan lebih mempersiapkan diri dalam proses pengambilan dan pengumpulan data dan segala sesuatunya sehingga penelitian dapat dilaksanakan dengan baik. 


\section{DAFTAR PUSTAKA}

Aan Komariah, Djam'an Satori, 2011, Metode Penelitian Kualitatif, Bandung: Alfabeta.

Alfitri, dkk. 2014. Penerapan standar akuntansi keuangan entitas tanpa akuntabilitas publik (SAK ETAP) pada usaha mikro kecil menengah (UMKM) perajin mebel desa godongsari kecamatan juwiring kabupaten klaten. Jupe UNS 3(2).135-147.

Asih \&Pratiwi.(2010). Perilaku Prososial ditinjau dari Empati dan Kematangan Emosi.Kudus: Universitas Muria Kudus.Jurnal Psikologi.1(1).

Fahmi, Irham. 2012. Analisis Laporan Keuangan. Cetakan Ke-2. Bandung: Alfabeta.

Erlina, Omar Sakti Rambe, dan Rasdianto. 2015. Akuntansi Keuangan DaerahBerbasis Akrual. Jakarta: Salemba Empat.

Glaser, Barney G. and Anselm L. Strauss. 1967. The Discovery of Grounded Theory.

Hadi, Nor. 2011. Corporate Social Responsibility.Yogyakarta: Graha Ilmu. Hanafi, Mahmud M. 2010. Manajemen Keuangan. Cetakan ke lima. Yogyakarta: BPFE.

Karisma Brigitta Dyah. 2016. Evaluasi Standar Akuntansi Keuangan Entitas Tanpa Akuntabilitas Publik (SAK ETAP) Dalam Penyususnan Laporan Keuangan Bank Perkreditan Rakyat (BPR). Skripsi. Fakultas Ekonomi dan Bisnis Universitas Santa Dharma: Yogyakarta.

Mahmudi, 2010.Analisis Laporan Keuangan Pemerintah Daerah. Edisi Kedua. UPP STIM YKPN. Yogyakarta.

Martani Dwi. SylviaVeronica NPS. Ratna Wardhani. Aria Farahmita. Edward Tanujaya. 2014. Akuntansi Keuangan Menengah Berbasis Kas. Jakarta: Salemba Empat.

Nugroho Adi, Rahman, dan Zulaikha. 2012. "Faktor-Faktor Yang Mempengaruhi Kemauan Untuk Membayar Pajak Dengan Kesadaran Membayar Pajak sebagai Variabel Intervening (Studi Kasus Pajak Orang Pribadi Yang Melakukan Pekerjaan bebas yang Terdaftar di KPP Pratama Semarang Satu)”. Diponegoro Journal Of Accounting.1(2).

Ratag, Suryani Miyoko. 2013. Perlakuan Akuntansi Capital Expenditure dan Revenue Expenditure pada PT. Bank Sulut. Jurnal EMBA. 1(3),179-181.

Parker, L. D. and Roffey, B. H. 1997. Methodological Themes Back to the Drawing Board: Revisting Grounded Theory and the Everyday Accountant's and Manager's Reality. Accounting, Auditing \&Accountability Journal. 10(2),212-247.

Peraturan Pemerintah Republik Indonesia No. 58 Tahun 2005 Tentang Pengelolaan Keuangan Desi Rahmawati 22 | 23 
Daerah.

Pratama Andi. 2014. Rancangan Penerapan Standar Akuntansi Keuangan Entitas Tanpa Akuntabilitas Publik (SAK ETAP) Pada Usaha Kecil Dan Menengah (UKM). Skripsi. Fakultas Ekonomi Dan Bisnis Universitas Islam Negeri Syarif Hidayatullah: Jakarta.

Poerwadarminta, W.J.S. 2005.Kamus Umum Bahasa Indonesia. Edisi Ketiga. Jakarta: Balai Pustaka.

Rakhmat, Jalaluddin. 2012. Metode Penelitian Komunikasi Dilengkapai Contoh Analisis Ststistik.Bandung: Remaja Rosdakarya.

Standar Akuntansi Keuangan Entitas Tanpa Akuntabilitas Publik (SAK ETAP) Sekaran, Uma. 2009. Research Methods For Business. Jakarta: Salemba Empat.

Steven \& Lina.(2011). Faktor-faktor yang Mempengaruhi Kebijakan Hutang Perusahaan Manufaktur.Jurnal Bisnis dan Akuntansi. 13(3), 163-181.

Sugiyono. 2012. Metode Penelitian Kuantitatif Kualitatif dan R\&D. Bandung: Alfabeta.

Syahrul dan Muhammad Afdi Nizar, 2000, "Kamus Istilah-istilah Akuntansi", Cetakan Pertama. Jakarta: Citra Harta Prima. 